\title{
Brexit and Financial Services: What Comes Next?
}

\author{
Michael Randal* ${ }^{\star}$
}

\section{A. INTRODUCTION}

Like many areas concerning Brexit, accurately predicting the outcome of negotiations concerning the provision of financial services and future developments is problematic. The Brexit White Paper states "In our new strategic partnership agreement we will be aiming for the freest possible trade in financial services between the UK and EU member states". ${ }^{1}$ At present, financial service providers based within the single market benefit from 'passporting' privileges. Passporting, formalised by the second banking directive of 1989², allows institutions established in one member state to freely provide and access services in other member states, with further passports issued to EEA states. Compliance with a common minimum regulatory standard as a condition of continued single market membership facilitates trading through passporting.

The UK and the remaining EU-27 states benefit from passporting due to the different concentration of expertise in financial matters across the Union. It is far easier to access financial expertise across borders through enabling the provision of a service rather than by relocating individuals. "Freest possible" trade would entail remaining a member of the single market. Yet there have been repeated statements that the UK will leave the single market. Accordingly, the relationship will at least be different.

\section{B. INTERESTS OF THE UK, SCOTLAND AND EU-27 IN NEGOTIATIONS}

Passporting rights create a strong incentive for institutions to maintain a presence in an EU member state. As CityUK states, "There are more head offices of banks in London than in any other place in the world... There are also over 250 foreign banks with an office in London. This is higher than nearest rivals New York, Paris and Frankfurt". ${ }^{3}$ Therefore, one of the aims in negotiations is to prevent overseas financial service providers from withdrawing institutional representation from the EU post-Brexit.

\footnotetext{
*University of Strathclyde School of Law. With thanks to Professor Aileen McHarg for her constructive comments

1 HM Government Report: The United Kingdom's Exit From and New Partnership With the European Union (February 2017) at para 8.25

2 Council Directive 89/646/EC OJ 1989 L386

3 TheCityUK, London available at https://www.thecityuk.com/about-us/uk-work-programme/new-u-kinteractive-map-page/london/
} 
Passporting rights are only one part of the equation however. If all single market states were equal, in theory it would make no difference in which state banks are established. There must be another reason why London specifically hosts a higher concentration of overseas financial institutions. This relates to the particular expertise located in London. CityUK state "London is the second largest global fund management centre. It manages more than $80 \%$ of hedge fund assets under management in Europe, $90 \%$ of European prime brokerage, and is the leading centre for management of European private equity funds". ${ }^{4}$ These statistics indicate that the UK has a highly tradeable service of value to the EU-27. Michel Barnier is reported to have affirmed to MEPs in January 2017 his preference for a "special" relationship to maintain access to the City post-Brexit. ${ }^{5}$ His comments reflect the risk that, unless a deal is reached, financial instability will spread to the detriment of national economies. This indicates that the sector is a trump card for the UK in negotiations.

From a UK perspective, losing passporting rights means it may no longer be as attractive a place for establishment, which may lead to institutional relocation and a detrimental impact on the UK economy. A 2016 PWC report ${ }^{6}$ indicates that the financial sector contributes $£ 32.4$ billion in taxation p.a. to the Treasury, of which $£ 17.8$ billion is from income taxes and $£ 16.8$ billion is from 'foreign' banks. In 2015 the gross value added (GVA) by the City was approximately $£ 81$ billion, with 751,000 people employed in total. ${ }^{7}$

Conversely, there may be other financial hubs that could benefit in the long term if institutions relocate. Two studies have shown at least half of any financial sector jobs leaving London could relocate to Frankfurt, with a minimum of 8,000 new positions created ${ }^{8}$ and that Brexit could create up to 88,000 new jobs in the Rhine-Main region. ${ }^{9}$ However, this would be extremely costly and there is no automatic guarantee that the same level of service would be maintained. Relocation would also take a significant amount of time, thus it remains in the interests of the entire EU-27 for financial service provision in the UK to continue.

C. MAINTAINING THE STATUS QUO: SCOTLAND AND NORTHERN IRELAND

\footnotetext{
${ }^{4} \mathrm{lbid}$

5 J Rankin, "EU Negotiator Wants 'Special' Deal Over Access to City Post-Brexit" available at https://www.theguardian.com/business/2017/jan/13/eu-negotiator-wants-special-deal-over-access-tocity-post-brexit

${ }^{6}$ PWC: 2016 Total Tax Contribution of the UK Banking Sector (November 2016)

7 TheCityUK, London available at https://www.thecityuk.com/about-us/uk-work-programme/new-u-kinteractive-map-page/london/. CityUK's figures are used in the UK Government's Brexit White Paper 8 Helaba Research Unit: Finanzplatz Frankfurt in Der Pole-Position Für Brexit-Banker (in German at https://www.helaba.de/blob/helaba/436294/e25e37900d3958a4627cae86ffd8fb59/finanzplatz-studie20170831-data.pdf)

9 WHU Otto Beisheim School of Management: Winning Frankfurt: Brexit Bankers' Welfare Effect Beyond Bringing Their Jobs
} 
Contrary to the Westminster government's approach, the Scottish Government has consistently advocated for retention of access to the single market, notably in 'Scotland's Place in Europe'. This document acknowledges that "[s]ectors like financial services have significant spillovers into other parts of the economy and, therefore, any slowdown here will impact more widely on people and businesses". ${ }^{10}$ It also discusses passporting ${ }^{11}$ and concludes that financial services should be one of the policy areas considered for further devolution. ${ }^{12}$ Scotland has the largest financial sector outside of the City, employing over 150,000 people and contributing $9.3 \%$ of the nation's economy. ${ }^{13}$ Professor Adam Tomkins, regarding the feasibility of a Brexit deal that works for the whole of the UK, stated, "the interests of the financial services industry in Edinburgh, which is a significant part of the Edinburgh economy, are the same as those of the City of London". ${ }^{14}$

However, divergence between the Westminster and Scottish governments concerning financial services could create differing interests in any second independence referendum. If an independent Scotland were to join the EU, it could develop its financial services sector in order to obtain passporting rights and freely provide expertise to other states. This would not be a simple process, but during any transition period, Scotland could develop innovative and unique tradeable services. The question mark in this situation is whether other EU states could develop similar expertise during the interim period.

It is also prudent to discuss how the question of the hard Irish border could inform the provision of UK financial services, although this is outlined as a speculative improbability as opposed to a realistic outcome. The European Parliament seems set to propose that Northern Ireland remains in the single market. ${ }^{15}$ Northern Ireland could retain passporting rights, including any subsidiaries of companies in London. If managed correctly, this solution could mitigate relocation outside of the UK to the benefit of Northern Ireland.

Compliance with new EU banking regulations would be problematic since they could be implemented in Northern Ireland without Westminster's input. Furthermore, Schedule 3 of the Northern Ireland Act (1998) provides financial services are a 'Reserved' matter for Westminster unless the Secretary of State gives permission otherwise. ${ }^{16}$ The current

\footnotetext{
10 Scottish Government: Scotland's Place in Europe (December 2016) at para 37

$11 \mathrm{lbid}$ at Paras 39(e) and 49

12 Ibid at Para $186(\mathrm{~h})$

13 TheCityUK, Scotland available at https://www.thecityuk.com/about-us/uk-work-programme/new-u-kinteractive-map-page/scotland/

${ }^{14}$ House of Lords Select Committee on the European Union, Brexit: Devolution Inquiry, 1 February 2017 at Q3

15 See J Stone, Brexit: European Parliament to Propose Northern Ireland Stays in Single Market available at http://www.independent.co.uk/news/uk/politics/brexit-northern-ireland-border-guyverhofstadt-single-market-customs-union-european-parliament-a7972596.html

${ }^{16}$ House of Lords European Union Committee, Brexit: Devolution (19 July 2017) at para 24
} 
Secretary of State, James Brokenshire, has indicated Northern Ireland will leave the single market. ${ }^{17}$ There are clearly many hurdles for this to be a long-term practical solution.

\section{ALTERNATIVES TO PASSPORTING}

The relationship between the UK and the EU-27 with regard to the provision of financial services is likely to take one of two forms, either. The first is through-a Mutual Recognition Agreement (MRA) or a Third Country Regime (TCR), a form of free trade agreement. The International Regulatory Statutory Group's (ISRG ${ }^{18}$ ) report on alternatives to passporting found that "the most favourable solution is likely to be for the UK and EU to enter into a bespoke agreement to allow mutual access to each other's markets. This could be on the basis of mutual recognition, or on the basis that the two regimes are broadly consistent (rather than strictly 'equivalent', under the approach currently used in the TCRs)". ${ }^{19}$ The principle of mutual recognition at present applies to goods and is a process in cross border trade whereby goods which are able to be sold lawfully in one member state can be sold lawfully in another State in spite of the product's lack of conformity with the latter State's technical rules. The ISRG report acknowledges that:

"The EU has entered into a number of MRAs with third countries (including Australia, Canada, Japan, New Zealand, the USA, Israel and Switzerland), although so far these MRAs only relate to trade in goods and it is not clear that they would be extended to the provision of services" ${ }^{20}$

An MRA in financial services would be unprecedented, but so is the withdrawal of a member state from the single market. The ISRG strongly advocate this approach due to the difficulties of the second option, of a TCR.ereation of a free trade agreement, also referred to as Third Country Regimes (TCR) or equivalences. For a TCR to be agreed by the European Commission three conditions must be met:

“i) The requirements under assessment are legally binding;

ii) They are subject to effective supervision by local authorities;

iii) They achieve the same results as EU rules". ${ }^{21}$

\footnotetext{
${ }^{17}$ See R Merrick, Minister Insists UK Will Leave EU 'As One Nation', Spurning Suggestions Northern Ireland Could Remain in the Single Market available at http://www.independent.co.uk/news/uk/politics/brexit-northern-ireland-border-single-market-customsunion-james-brokenshire-european-parliament-a7976996.html

${ }^{18}$ Comprising practitioners in the financial and professional services industry

19 ISRG, The EU's Third Country Regimes and Alternatives to Passporting (23 January 2017)

20 Ibid at p.138

${ }^{21}$ European Parliament Briefing: Third-Country Equivalence in EU Banking Legislation
} 
ISRG's concerns are that although there are examples of equivalences in operation, they are of a limited scope and provide insufficient data from which to draw firm conclusions. Chapter 13 of the Canada-European Union Comprehensive Economic and Trade Agreement (CETA) concerns financial services. It seeks to liberalise trade based on the WTO's General Agreement on Trade in Services by focusing on cross-border supply, consumption abroad, commercial presence and presence of natural persons. In addition to a lack of conclusive data, it appears that any TCR would require the UK need to comply with WTO principles. This would preclude the UK from favouring its own financial institutions under the most-favoured nation rules. Peihani concludes, "CETA is also a poor policy choice given the significant difference of the UK's and Canada's trade profiles"22 and should not be the model the UK adopts.

Both options require the UK's regulatory standards to be sufficiently comparable to the EU-27 in order to gain access to the market. As Moloney notes, these arrangements mean that it is unlikely that there will be a great divergence in core governance between the EU-27 and the UK. ${ }^{23}$ This is further supported by the fact that the UK and the EU are both members of the G20 and are parties to the Basel Committee on Banking Supervision, meaning both would be required to adopt resulting financial service standards agreed in these forums. Until the provisional date of withdrawal of March 2019 (excluding any transition period) the UK is still required to implement Directives and Regulations. This includes in financial matters and therefore includes major pieces of policy, such as the MiFID (Markets in Financial Instruments Directive) $1{ }^{24}$ provisions, which seek to improve protection for investors by reinforcing transparency and has a provisional entry into force date of January $2018 .^{25}$

\section{E. OPPORTUNITIES AND INNOVATION}

Thus far, this article has highlighted the potential dangers of Brexit for financial services across the UK. However, 'necessity is the mother of invention' and the sector is susceptible to technological innovation. Although ultimately it is likely that only the peripheral areas of financial regulation that will change, the UK may be able to develop a more bespoke regulatory system and exclude some EU provisions, which may be perceived as being inefficient, to create a competitive advantage. ${ }^{26}$ For example, this could include development of and investment in Financial Technology (FinTech), such as peer-to-peer lending (P2P) and

\footnotetext{
${ }^{22}$ M Peihani, "Brexit and Financial Services: A Tentative Analysis of Possible Exit Scenarios" (2017) 5 J.B.L 357

${ }^{23}$ N Moloney, "Brexit and EU Financial Governance: Business as Usual or Institutional Change?" (2017) 42(1) E.L.Rev 122

24 Council Directive 2014/65 OJ 2014 L173/349

${ }^{25}$ See P Snowdon et al, "MiFiD II/MiFiR" (2014) 120(Oct) Compliance Officer Bulletin 1

26 See B Reynolds and T Donegan, "Brexit - Opportunity for a Reboot of Financial Services" (2016) 31(12) J.I.B.L.R 613
} 
challenger banks. ${ }^{27}$ Akintewe states that "[w]ith Scotland's established financial infrastructure, Fintech presents huge opportunity for the Scottish economy". ${ }^{28}$ However he also states that there are concerns regarding, for example, consumer protection and money laundering. Moloney states that Fintech will cause a greater shift in EU financial governance than Brexit ${ }^{29}$, indicating not all potential changes in the financial services sector are attributable to Brexit.

Reinvention could also include emerging markets in Islamic finance. The Islamic Corporation for the Development of the Private Sector currently ranks the UK as $22^{\text {nd }}$ out of 124 countries for Islamic finance offerings ${ }^{30}$, making it the leading European State in this area. This sector could be developed further to create a niche to mitigate any potential negative effects through relocation of services to facilitate trade with Islamic finance centres beyond the EU. These services could later be provided to the EU-27 for, particularly in an independent Scotland in the single market. ${ }^{31}$

\section{F. CONCLUSION}

On the evidence presented, it is clear that the provision of financial services is a priority in negotiations for the UK, including the Scottish government, and the EU-27. Due to the decision to leave the single market and the likely loss of passporting rights, the outlook initially appears to be bleak. Yet when further consideration is given to the alternative arrangements of mutual recognition and free trade agreements, it is likely that core regulation will remain similar between the EU and the UK. If there are to be changes, it is likely to be at the edges of financial regulation. This may act as a catalyst for UK financial services to reinvent themselves and be a pioneer in finance in the longer term. However, in the short to medium term the primary concern has to be on the guarantees given to financial institutions to disincentivise relocation of services. This clarity is needed in the interests of financial stability from both the UK and EU-27 sides, which at the time of writing is not forthcoming.

\footnotetext{
${ }^{27}$ See L Lu, "Financial Technology and Challenger Banks in the UK: Gap Fillers or Real Challengers?" (2017) 32(7) J.I.B.L.R 273

${ }^{28}$ A Akintewe, "Scottish FinTech and VC Funds: So Much Promise, So Many Pitfalls" (2017) Spr In House Lawyer 70

${ }^{29}$ N Moloney, "Brexit and EU Financial Governance: Business as Usual or Institutional Change?" (2017) 42(1) E.L.Rev 122

30 ICD, Islamic Finance Development Report (2016) at p.12

${ }^{31}$ For a detailed consideration of Brexit and Islamic Finance see S Morrison, "Brexit: Bane or Boon for Islamic Finance and Banking?" (2017) 32(7) J.I.B.L.R
} 